\title{
REDEEMING THE CANON: TRANSDISCIPLINARY COLLOCATIONS
}

\author{
Felix NICOLAU* \\ University of Lund, Sweden \\ Technical University of Civil Engineering Bucharest, Romania
}

\begin{abstract}
The canon in the English speaking world has been remolded under the influence of later developments in technology and media. Posthumanism and Communication and Performance Studies push forward the demythization - initiated by the Cultural Studies - of the aesthetic isolationism of the New Criticism. The new developments do not dispute the primacy of the aesthetic/truthful criteria used for informing the canon, but they disclose the fact that we cannot ignore the complexity of contemporary society. My study envisages new approaches in selecting items for the new arch-canon, with reference to specialized canons and also personal canons. How much is utopia and how much is dystopia in building an arch-canon in the English speaking world? Can we create a canon which will serve pure communicative purposes instead of the customary colonialist ones?

The canon is subject to fashion too, but fashions know inner delimitations. Every time a certain fashion is resurrected, it displays new encodings, too, superposed to the old ones. Nothing in history has been resumed between the same coordinates. A trustworthy canon cumulates many fashions and combines them into a multi-discourse super-fashion. But, in the end, the canon cannot contest the perishable ingredient in its composition. Even Harold Bloom acknowledged that when he selected only twenty-six writers to support his point of view. What raises the canon above the run-of-the-mill fashion is that it never wanes entirely; it simply substitutes some of its components, modernising its structure. The canon is an ever-lasting system endowed with the ability to eliminate and draft values in accordance with cultural imperatives. At the same time, the survivalist representation of the canon is limited, as its main mission is to safeguard and propose values. That is why the canon has to be formed with an eye to the updated chart of values; otherwise it would completely miss its momentum and power of influence.
\end{abstract}

Keywords: canon, digital literature, media, communication, performance, Performatism

\footnotetext{
*felixnicolau1@gmail.com
} 
The last major contribution to reinforcing the canon came in 1994 and was the work of Harold Bloom. The book, Western Canon, and its content fiercely defended the most promoted literary works of the self-titled civilized world. The defense was against the siege of cultural studies and its accuse that the old canon manifested a crass lack of representativeness. The purpose of my article is not to resume Harold Bloom's arguments against non-aesthetic claims of rebalancing the canon, but to reorient the debate towards the opening of the Canon in terms of scientific advancements. It is not about agency and democratic representativeness that I intend to write, but about the reconfiguration of the canon in relation to communication studies, performance studies, readerresponse theories, and digital literature. By analyzing these humanistic perspectives in connection with the literary studies and reader-response theories, I envisage the configuration an arch-canon which should include side-canons able to assimilate the most precious works in various fields and genres. We can even outline the development of a super-arch-canon which would absorb contributions coming from disparate scientific fields and facilitate the communication between them. The final target is to build a transdisciplinary structure of excellence as stimulant for a mathesis universalis.

Harold Bloom, in the Western Canon, selected only twenty-six sine qua non writers and, invoking Giambattista Vico's New Science, where human history was distributed in three phases - Theocratic, Aristocratic, and Democratic - introduced another one, the Chaotic Age [represented by Freud, Proust, Joyce, and Kafka (Bloom 1994: 2)]. Bloom did not expel this newly proposed Age, as it was also the container of beauty and strangeness, in the way Walter Pater desired for Romanticism.

\section{WHAT HAS HAPPENED SINCE 1994 TO THE STATUS AND CONDITION OF THE CANON?}

In the epoch of convergence and performativity, the competition, but also the interpenetration of disciplines, have become inevitable. Is it a loss from the point of view of aesthetics? It may be for the aesthetics of the 17th century, when an artistic product had to involve wholeness, sublimity and assimilation of tradition. In postmodernity, the manifestations of beauty became versatile and pluralistic. Contemporary culture would adopt an anachronistic position if it scorned the contributions of cultural studies, translation studies, performance studies, critical media studies and so on and so forth. The former canon made room for an interpenetration of canons. The new modality of realizing the selection for the canon requires open-minded and well-read critics, able to promote the most vital values resulted from the study of cross-sections through the concentric canonical sphere. The new arch-canon is a "canon-in-the-cloud" that lets in and out 
elements of excellence coming from the satellite-like and interdisciplinary canons.

This complex and heterogeneous canon is informed more and more by poles of radiation and influence - for instance translators and anthologists -, not only by critics: "A translator and an anthologist (who not infrequently are one and the same person) are coauthors of the canon to a degree that has never been sufficiently acknowledged" (Wilczek 1689). Besides, media are the most important propeller of the value-engine. At the same time, in a media-dominated frame, the game of offer and demand implies fast and unpredictable moves. The privileged position of being listed at the stock exchange of the arch-canon will be shorter than it used to be during the Canon contemporary with the Theory. The new canon has to face the plethora of multi-field theories. To ignore the fact that media will play an increasing role in promoting (non)values would mean to abandon the fight for intellectual authority in a heterogeneously constructed world. Even a pillar of modernism like T. S. Eliot has been recently perceived as connected to the values of postmodernism - i.e., to the open text, to the solicitation of the reader's participation, and to the indeterminacy of meaning (Ashton 2). Every -ism seems to be related to a new form of communication.

\section{CANONICITY AND COMMUNICATIVE DISPOSITION}

Conditions of communication are inflected by habitus. Apart from Bourdieu's definition of the notion, Rapport and Overing (2) emphasized those transposable dispositions which generate structured social practices. Understanding the conditions of habitus allows the generator of discourses, endowed with agency, to insert in them manipulative or propagandistic ingredients. Thus, literature can very well function as a platform for public relations or advertising. Every author/publisher assesses readers' objectives and needs before elaborating narratives. Postmodernism also resorted to multi-layered discourses in the posttotalitarian epoch and revived the importance of cultural symbols.

In order to deconstruct the toxic discourses of a MacDonaldized and Disneylandized postindustrial society, reception has to resort to mediated discourse analysis as it includes the social identities and social relationships made possible by certain discourses (Hyland and Paltridge 10). Actions are transformed into texts and texts into actions in a never-ending entextualization. The reception of literature is akin to an intralingual translation and every literary encoded message is decoded in panoplies of meanings, depending on the level of communication between the works of art and their readership. Respecting the pattern of everyday communication, the feedback offered by readers is influenced by context, noise, mood, level of decoding, filters and so on.

Getting closer to Cultural Studies, communication implies an exchange of points of view, if we are to take into consideration genuine communication: 
non-biased and detached from agenda setting schemes. Even in the cultural field we are trapped in what J. Habermas called communicative actions. Culture would be blocked at the level of samizdat without unless it be helped by communication to establish its context (Knoblauch in Luzio, Günther and Orletti 5). Thus, intercultural communication relies on rationality, especially on linguistic rationality. In order to gain access to dialogue - and what are reception or hermeneutics if not genuine dialogue? -, communicators have to be able to perceive different cultures from a perspective of informed understanding (Corbett 2).

The interdisciplinarity of the new arch-canon relies even more on the fluency of communication with the consumers of values. In the context of a liquefying world, the questions of transitoriness, relativism, and contingent values suggest a versatile and negotiable canon. Obviously, the conflict with the old, accumulative Canon, shared by intellectuals and specialists around the world, is unavoidable. One argument in favor of the new system of valorization is that the old-fashioned method of sanctifying artefacts actually sidelines their impact on the cultural market. The "classical" way of legitimating works for their inclusion into an ever-lasting pantheon may be a cultural practice of the past. Some fields have always been more exposed to canonicity than others and, consequently, more acutely informed by political and social forces (Sela-Sheffy 141-42). On the other hand, many ideology-driven influencing factors cultivate the confusion between a valuable product per se and its effect on the commercial or ideological market. That is why communication theories can be helpful in telling apart the genuine value-consumption from the artificially stimulated one. By "artificiality" I understand mediocre criteria used in the selection and promotion of sub-values as first-hand values.

\section{TRANSDISCIPLINARY AND PERSPECTIVIST DISCOURSES}

The construction of every canon necessitates interactivity/communication but also hedging measures so that the selected values would not have their position too early disputed by other competing would-be values. Genuine communication is founded on a hierarchy of hypotheses, although the top-down distribution inside the canon is constantly debatable.

The probability of misunderstanding intervenes when the factors involved in negotiating the canon lack mindfulness, as they are not able to refresh their grid of selection and to be open to new information and multiple perspectives.

If we want to maintain the creation of the canon at a dialogic level, we have to strive for obtaining a flux capable of achieving aesthetic elevation. Social constructionists state that the constitutive dialogue creates and alters not only relationships, but also the entire social construction. Thus, our discussions 
are part of the all-comprising competing discourses, but also of the oncoming discourses. Present and future communication forms a dialectical flux which makes impossible the predictability of an issue. Nothing manages to preserve its autarchic state. This is quite normal if we admit to the spiraling inversion of the contrasting voices in a relationship: the dominant role is assumed in turns, depending on the circumstances.

The usefulness of the theories of communication for the explanation of canonicity is undisputable. They prove that everything in the universe comes under representations of communication. Likewise, they make explicit the complexities and obstacles that inform the process of communication. Building the canon coincides with investing continuously in communication. The impasse is that communication can be genuine - in a utopian representation - or - more often than not - fake, biased, or mimicked.

\section{PERIPHERY AND SOCIOLECTS}

There are many influencing factors in the process of (re-)shaping the canon. Local and non-didactic canons are more predisposed to ableism as they pay significant tribute to social success. The process of acculturation intervenes periodically and with the merging of cultures canons blend too. Ageism can also affect the structuring of the canon. Canons are informed by political correctness too. Many works of art become dated or politically incorrect and later epochs do not find them irreproachable. For instance, some works can be banned from the canon under the accusation of chauvinism. Even aesthetic selections are a matter of chronemics, evolving under specific temporalities.

This is why the arch-canon needs to be as cosmopolitan and flexible as possible. But in spite of the existent lingua franca at a certain moment, cultural noise invariably influences the climate of selection. Translations are salient in this case and they are the result of biased negotiations. Canons develop their own "languages" as they target larger or restricted categories. Side-canons intently assume different structuring principles in order to highlight injustice and marginalization; but, without aesthetic buttressing, they get outdated sooner than later.

On the other hand, colonialism takes the form of enculturation. The ethos of a group is absorbed into a more central culture at a certain moment. The center invades the peripheral canon. As in pragmatics, a certain culture attains the felicity conditions for its canon to be the most successful. The confrontation of canons (colonization and reverse colonization) advances from heterophily to interlanguages as an intermediary stage in intercultural communication.

The initial mixophobia of the central canon has made more and more place to the melting-pot approach. Thus, the canonizing process is ever-changing 
and includes, besides aesthetic/truthful contributions, ingredients that belong to various sociolects.

\section{THE CANONICAL DEBATE: MODERNIST AND POSTMODERNIST CONTENTIONS}

The elaboration of the canon was influenced by the tumultuous relationship between modernism and postmodernism. For instance, Jennifer Ashton insisted on the transformations suffered by the regime of texts. The Eliot-type modernism adopted the autonomy of the text (or what postmodernism would call the "closed text") and the determination of its meanings, whereas the postmodern text preferred to stay "open" and indeterminate in terms of meaning (Ashton 1). Reader-response theory tries to reduce textual ambiguity, but ultimately this is an issue related to the cultural level of the readership. The acceptance of an increased openness for our messages implies a reduced intention of dominance in the act of communication.

Conversely, the multi-faceted profile of postmodernism, under the umbrella of a complex and contradictory postmodernity (Sharman XI), allowed for a softened approach to conceiving the canon. In such conditions, there resisted no solid, impenetrable frontiers between stylistic and socio-cultural phenomena. Zygmunt Bauman contested the cultural dams built by high modernism. For him, modernity was a process of liquefaction from the start. If solids cancel time, liquids, on the contrary, boost time perception (Bauman, Liquid Modernity 2). Mainstream canon is thus overflowed by tributaries which melt the "solids" (ibidem 4). Building up the canon could be fueled up by liquefaction or, oppositely, could be pulverized into countless petty, irrelevant selection criteria. Even Bauman warned about the decomposing blabbering of culture industry. The "exhilarating freedom to pursue anything" and the "mindboggling uncertainty" as to what is worthwhile pursuing induce a state of "all-deriding, all-eroding, all-dissolving destructiveness" (Bauman, Intimations of Postmodernity VII-IX). The key word here is "all". Without it, we could consider the creative destruction's utility, as it dismembers fossilized structures and invites to a more flexible reassembling. Liquefying structures may help the process of canonization as much as they may break it into countless exchanges of insignificant content. Too much freedom to pursue anything in a society enjoying destructiveness leads to axiological confusion. This abyss of relativism engenders irony as defense in front of confused axiology.

Irrespective of individual preferences, one cannot reject the fact that contemporary culture has become polycentric and pluralistic. Quantum physics, the theory of chaoplexity, theories of chaos and of the fractal have all contributed to put the previous epistemological certainties into perspective. Nowadays it is plausible and scientifically sustainable for opposed stances to 
coexist: creation is accompanied by destruction, randomness by determinism, disorder and unpredictability by strict rules (especially in coding). We speak more and more about a posthuman body and about cyborgs, together with the correspondent ethical sets. How could we maintain the same centuries-old criteria for constituting the canon? This is a world more and more perceived as a media-projected concoction. The risk of resisting the new developments may lead to the sheer disputation of the necessity of a Canon: "Deconstruction's effect on the canon has been to open it, or it should be. Indeed, it should be more radical than that. Under the aegis of deconstruction there should be no canon" (Adams 760).

\section{THE CANON IN RELATION TO DIGITAL LITERATURE}

In parallel with keeping the rhythm with the contemporary literature and critical studies, I analysed the process of selecting aesthetic values in several humanist fields. We have to take into account that innovations inside the canon have never been so accelerated. Like the mainstream culture, the hierarchy was pulverized into many hierarchies. A few decades ago, many writers were still nostalgic as to the function of the arch-critic; nowadays they realize that such a dream is anachronistic. This transformation has been supported by the multiplication of printing houses, which induced both anarchy and democracy. In order to be persuasive, the literary critic has to assume a propagandistic role, too. The new public consumes literature and quasi-literature in an undifferentiated way. A mannerist and ultraconservative methodology for assembling the hierarchy affects the readers' response. Hiding behind untranslatable jargons impedes the communicational process and mutual influencing. Contemporary life may be less elevated, but it surely is more complex and heterogeneous. We all live under the "Harlequin countercultural umbrella" (Gair, The American Counterculture 9). In such conditions, the intellectuals responsible for shaping the canon should be in possession of an encyclopaedic cultural background. Decentralizing the critical action assures the avoidance of the tendency towards the unjust eliminations and the preservation of arthritic cultural products.

The canon-makers, as leaders of opinion, are bound to take heed of the new forms of creativity and agency. We live in a culture bombarded with computer-generated movies wherein readers benefit of choices of narrative trajectories and endings in virtual space. The "participant novel" or "interactive fiction" inform a larger-than-life space which integrates asymmetrical fractional dimensions, infographics, holography, informatics, supersonics and many others. Long ago, deconstruction dismantled Saussure's binary model of the sign. Inside the experimental space, the most creative one, of course, signifiers play freely.

Although Theodore Nelson published the book Literary Machines in 1981 -here he launched terms like hypertext and hypermedia - very few writers 
and critics know about these concepts. Nelson hoped that with the help of Xanadu, specially designed software, he will be able to unify the electronic literature. Hypertext can be understood as non-sequential writing able to branch out. The readers would have thus the possibility to choose their reading itinerary. The interactivity of the digital literature is assured by the links which connect bits of text which can be accessed in a fortuitous order. Readers create their own fictional texts in a nonlinear manner. Hypertextual fictions emerged at the beginning of the '80s (Michal Joyce, Afternoon. A story, 1987). Chronology, spatial vicinity and a fluent plot, distributed on chapters, were abolished. The text became a gallery of signifiers, instead of a structure of signifiers. There was no end and everything was reversible.

In Nelson's opinion, this new type of text arrangements is a docuverse that is the sum of all texts existent in the global network. The reader is transformed into an author-dispatcher. Some textualist ideals are shared: texts are capable of self-generation and there is no clear boundary between the author and the reader. The new type of communication implies that nobody reads, but everybody writes. The aesthetic valuation becomes a difficult enterprise. The reader is invited to become a combinatory writer.

Differently, in the last two decades SMS poetry has developed vertiginously. There are competitions and prizes offered for this new literary branch. Mobile phones become books and, in addition, Espen Aaresth baptized hyper-literature "ergotic literature". There is an increased liberty of reading following different vectors. The work upon the form influences the content, too. The archetype of this dislocating literature can be found in Charles Dickens's serials, wherein plot and characters were changed depending on the reader's will. By offering the reader the possibility to mix fragments, the author establishes a literary partnership. The slogan of the hyperwriters is "Screening is way up!”

B.S. Johnson, in 1969, used in The Unfortunates unbound pages which were to be shuffled and read at chance. Every page became a texton, and the chosen orders were called scriptons. This non-linear chaotic reading order offered readers the chance to become "readers-as-authors." There is, then, an intertextual version of hyperliterature which is named derivative work. In Ftrain, Paul Ford included thousands of links, references, and fragments from other texts which could be remixed.

Nora Boyle dwelled upon the digital reading in connection to hypertext (HTML). She invoked Einstein's theory of relativity, which specified that time can move backwards and forwards. The on-line cyberwriters are called Digerati; they do not write, they transmit. Could the building of the canon ignore these new developments? In 2005, the Dutch Government appointed a Committee for Developing the Dutch Canon (http://cntcocn.nu/informatics. Aspx?id=5\&ean/=e). 
We may be heading towards a "low frequency" literature, as Jonathan Carr, editor at Minima Magazine warned. The medium does not simply wrap the text, they interweave now. But hyperliterature is not only about shuffling chapters and pages, but also about intensifying the written material with the help of sound and image. The leap from one narrative hub to another, with the help of links, announces many potential stories. The text is not possessed but rented. The original becomes fluid and generates simulacra.

The theory of cybertext considers that all texts are machines projected to accomplish certain actions. For instance, Mark Eskelinen's Interface, from 1997, is a tripartite work that begins as a novel and is taken further on internet in an equation built on the authorial input and the readers' feedback.

Interactivity tackles combinations with kinetic techniques, as in Jim Rosenberg's Intergrams (1997). Here, the simultaneities (the layers of text are juxtaposed so that by moving the cursor one can read separate layers) build a syntax "externalized" in graphic symbols which interrelate the fragments of text. In Robert Kendall, A Life Set for Two, 1996, readers can select "the atmosphere" of a text from a "menu."

The first hypertextual novel, Afternoon. A Novel, by Michel Joyce, consists of 539 lexias $^{1}$ and 951 links that connect them. This structure enables various styles of reading (a different set of lexias, in various orders), which engenders different stories, or a frame-story which includes the reader's stories too. This process was coined humanistic computing. An acronym for these innovations was created: MUD (multi-user-domain).

Several mainstream writers strove to trespass the boundaries of traditional literature. Vladimir Nabokov's Pale Fire contains a Foreword followed by a poem, whereas the plot consists of an extensive commentary and an Index. The reader can go through and interpret the four sections assuming an optional order. Julio Cortazar's Rayuela has 155 chapters. The author proposes in the beginning a certain reading order, but the reader may ignore it and opt for other approaches. Tjhere may be added also Italo Calvino's If on a Winter's Night a Traveller, or Jose Luis Borges's The Garden of the Forking Paths.

There have been more than twenty years now of experimentation in a field which affects not only the form, but also informs the content of literature. A canon neglectful of these developments would be on the brink of obsolesce.

\section{PERFORMATISM AND THE POST-POSTMODERN CANON}

Performatism, one of the most remarked trends within post-postmodernism, proposed a holistic approach able to absorb artistic suggestions into a unitary, homogenous whole. The new hero is the hacker and he is called to be the

\footnotetext{
${ }^{1}$ Blocks of text or the equivalent of a page in digital literature.
} 
Messiah of the cyberspace descended from sky(pe) to save a post-industrial and post-apocalyptic humanity heading towards a civilization of the mind.

Published in the second issue of Anthropoetics Magazine by Raoul Eshelman, the Performatism Manifesto commences by accusing postmodernism of having cuffed the subject. In order to define a performance, appeal is made to John Austin's theory about speech acts. A performance would stand for two different representations: for modernism it represented the annihilation of borders between life and art, whereas for postmodernism it integrated the subject's human body into an artistic context. It results that in order to be totally free, the absolute subject - originating in Fichte's doctrine -, should give up the artistic conventions, too.

A first model of "concentrated, holistic" subject was "Against Theory", an article published in 1985 by Stephen Knapp and W. J. T. Mitchell. Three fundamental conditions of interpretation were debated: the authorial intention, the text, and the reader. The hermeneutical criticism focused on the authorial intention, the deconstructionist criticism of the sign, and on the relativistic criticism of the reader. Independent of the analytical approach, the subject manifests herself in holistic "performances."

Approximately at the same time, Eric Gans proposed a Generative Anthropology relying on a sign conceived holistically and performatively and also on a "limited" or unified subject. The generative anthropology is a minimalist theory about the origins of language, inspired by René Girard's theory of victimization. The previously animalized social order became a human one and it was founded more on the semiotic representation than on the physical imitation (mimesis). As in Girard's "founding murder", the first use of the sign accumulates a sacred load. More or less, Gans ontologised and sacralised Derrida's différance. Two authors are seminal for performatism: Viktor Pelevin, with short stories and the novel The Small Finger of Buddha, and Sam Mendes, with the film American Beauty.

In the performatist epoch, the chronotope allowing for the choice between possibilities is favoured. Everything is permitted to subjects in order to preserve their integrity and freedom of choice. The authors of performatism make it clear that they encourage self-therapy, so that subjects can counteract aggressive milieus by firmly imposing their own personality. Among the goods that performatism considers to be dispensable is life also, with all its selfish modalities of manifestation.

Free of revolutionary ambitious, the founders of performatism declared that the separation from postmodernism happened gradually. It focused on blueprinting a holistic, discreet subject. Another rebellious offspring of postmodernism is conceptualism. Viktor Pelevin wrote about this break-away in his short-story from 1999, The Warning Token on the Wall. The plot is about vibrationalism, an imaginary artistic movement claiming that we live in an 
oscillating world and that we are merely a collection of oscillations. The error of conceptualism, in the opinion of one of the vibrationalists in the short-story, is that it tries to describe the concept. As for the vibrationalism, it tries, reversely, to put away the frontiers of the concept. Thus, the specificity of vibrationalism would be the possibility for the sign and for the subject to overpass the subject/object dualism towards a unifying performance. We get back, as a matter of fact, to performatism because it continuously tries to transcend irony, whereas postmodernism endlessly generates irony. The end of the manifesto highlights five main characteristics of performatism:

1. There is no more resort to quotations crowding or to authenticity. Once intertextuality was abandoned, the ritualized dogma comes into use again. History, too, is recovered under the shape of an empirically framed subject. As to narratives, they are expected to get back authoriality, that is, the author as an organizing and selective force.

2. The subject appears solid or opaque. It can be stupid, naive, confusing, shallow, firm or heroic, but not constantly cynical or ironic.

3. The passing from an endless temporal postponement to a conjugation of opposite forces at the time being.

4. The transition from the metaphysical pessimism to metaphysical optimism. The metaphysical targets are not death and the related realities (the void kenosis, absence) anymore, but "fictionally framed states of transcendence (resurrection, passage to Nirvana, love, catharsis, fulfillment or plerosis, deification etc.)” (Eshelman 2001:8-9).

5. The return and rehabilitation of the phallus as an active and unifying agent of performativity. The phallus as a positive frame for the vagina and vice versa. All in all, a tendency towards belittling possession. Love is more important than dominating the opposite sex.

The message actually is simpler than the lofty package it comes wrapped in: simplicity, good will, honesty, and feeling for daily revelations (epiphanies). Eventually, a certain purity of soul kept away from the religious approaches. To lively minds, performatism might appear slightly jelly-like and monotonously univocal; a sort of Ghandism without a definite target, a strictly contemplative passivity. On the other hand, taking account of the ferocious rivalry in all the fields, but mainly in the artistic ones, the attitude manifested in the manifesto is peculiar. Modernism and postmodernism have transformed art into a sophisticated profession. A lot of technique, loads of marketing and PR, but very little genius and scarcely any passion - the only ones able to extract from anonymity surprising aspects of the real and reality. Unfortunately, the enemy of the performatist signifier is exactly the corresponding signified - a rather blurry one. 


\section{DISCOURSE THEORY AND CONTEXT APPROACH IN SHAPING THE ARCH-CANON}

There are state-of-the-art studies about practices, utterance interpretation and processing, and acts of speech. The pragmatic inferences begin to rely more on analyses of non-assertive acts of communication. The pragmatic turn values sentence in communication more than sentence structure. The new developments in the realm of the philosophy of language connect it overtly to communication theory. The phenomenon is closer to continental European pragmatics than to the Anglo-American one. The former is takes interest in macro-pragmatics, which includes socio-pragmatics, cross-cultural and intercultural communication, and ideology. This integrative development is very useful for hermeneutics, especially when, allegedly, the researcher tries to clarify Gricean implicatures, which are haphazard sayings or meanings without a limpid expression, or "the speakers implicate while readers infer" (Allan \& Jaszezolt 4).

If linguistics is informed by idealizations, then applied linguistics is accountable for linking languages to thinking in matter-of-fact everyday life situations. The same happens with literature: the reader-response approach is preoccupied with the transaction between the artefact and its readership in relation to the context wherein this is accessed.

Postmodernism showed that literature and language are not selfcontained, neutral systems, but politicised forms of thinking and feeling. In order to identify and understand these cultural ingredients we need a multifunctional hermeneutics. Noam Chomsky pleaded for a universal grammar but nobody could plead for a uniform reception and assessment of literary products. The mediated discourse analysis posits that all actions are mediated through cultural tools. It results that our discourses are both situated practices, tied to quantitative and qualitative configurations, and community practices, tied to various communities within particular disciplinary narratives (Hyland and Paltridge 13). Through entextualization we reify language as text, much in the same vein as the structuralist approach. Structuralists were more preoccupied with the structures of language which made possible linguistic performance than with the actual performance in its multiple representations. Langue was more important than parole. Signs, in the Saussurean tradition, generated sense through reciprocal reference and not through interaction with an external and hybridized world. Selection and combination were realized strictly sintagmatically (Barker \& Galasinski 4). It was Roland Barthes who understood to subsume all cultural practices to semiotic analysis.

For the literary discourse to function at all levels, Grice's cooperative principles (1975) are still standing: the maxim of quantity (quantity of information), the maxim of quality (adequate evidence), the maxim of relation (relevance), and the maxim of manner (coherence, concision). But, of course, 
they are imperative only at the communicative level, otherwise, the literary discourse would surrender to redundancy, deformation, irrelevance and prolixity or ambiguity. However, the phatic function would not be annihilated through these tactics, only diminished in terms of a thinned public.

Contemporary literature covers more and more frequently the full spectrum of linguistic signs (organized by C.S. Pierce into a triad: iconic, indexical and symbolic). Pierce's type of semiotics is processual, paying attention to protean contexts, whereas Saussure's was linguistically oriented and based on the arbitrariness of the linguistic sign. A triadic paradigm was opposed to a dyadic one. Then, with the advent of poststructuralism, the conditions of truth became loose, if not evanescent. As to our topic, literature does not have to stick to the principles of logic in order to secure a public. Literature professes an inter-discourse communication, which results in access to all milieus (Scollon and Scollon 2).

The epistemic theory of vagueness contends that there is no firm borderline between disciplines. Accordingly, a reality is neither true, nor false, everything depending on context. Thus, this theory uses concepts and ideas as "contextuality" and "accommodation", in the wake of Grice's cooperative principle and the associated conversational maxims. The levels of specificity will vary depending on the situation (Connor and Upton 1).

Again, language in use flexes itself in relation to the status of language users, to the context of interactions, and to the communicative goals pursued by communicators. Truth-conditional semantics analyses sentence meaning in the light of formal rigour and logical plausibility, but in compliance with evolving states-of-affairs too. To these, the meaning supplied by other sources has to be added. Language theories may enlarge their scope when they confront with the use-centred, social-interactionist views on language. We hereby get closer to speech acts and their intentionality. In much complex interactions, the speakers adjust their utterances to suit the hearers, while also being mindful of the context and of the assumed shared background knowledge, otherwise hearers tend to become overhearers. From the point of view of pragmatics, an overhearer may misinterpret the message for want of appropriate contextual information. In this equation, a locutionary act is followed by an illocutionary one which also assumes a performative dimension. Finally, the perlocutionary act evades the intentionality of pragmatics and enters the sphere of the theory of discourse. As we know, pragmatics includes the study of speakers' meaning, of contextual meaning, and how speakers communicate more than they utter. This involves presuppositions, conversational implicatures, references, deixis or "pointing", and speech acts. Language is not an organism developing by its own accord, but a collaborative construct belonging to linguistic communities. Theory welded to individual functional acts could create what Searle coined in 1969 as "felicity 
conditions.” According to these, the speaker will provide that valuable (sincere) information which is desired by the hearer.

The "social turn" in language studies and the parallel "turn to discourse," appeared towards the end of the 20th century in the social sciences, redirected researchers and theorists towards the "processual", "constitutive" and "ideological" aspects of the language. Culture has become gradually understood as cultures which include also institutions and mentalities. Linguistics accepted connections to ethnoanthropology in what was called the "postmodern turn." Consequently, a cross-fertilization of discourse analysis and linguistic pragmatics became possible. The result was discursive pragmatics, a concept theorized by Jan Zienkorovski, Jan-Ola Ostman and Jef Verschueren in their eponymous book published at John Benjamin's Publishing House Company in 2011. The stress falls on points of convergence, eclectic studies of real-life discourses and interdisciplinarity. Ethnomethodological conversation analysis also focuses on common-sense reasoning and social action work.

These new perspectives understood individual agency and power structures as dialectically interrelated. The same type of tension persists in Discourse Studies: appeared as a reaction to structuralism in anthropology and linguistics, the discipline includes both a theory of social life and of language. Ethnomethodology preceded conversation analysis which confined itself to the study of the "here and now" of interactions, which mainly described rules governing interactional patterns, that is to say turn-taking structures and specifics of relevant conversations. Umberto Eco also referred to the importance of the Dynamical Object as a terminus a quo, meaning of course the language in action, as a flux between interpretants (Eco 3).

For the French poststructuralism the social space was a discourse containing sub-discourses which organized regimes of power and inequality. Unequal opportunities, social-leverage and marked identities were legitimated through ideologies. It is basically what Foucault understood by the historical nature of discursive practices. If there is no discourse free of ideology, free of paradigm, then it is obnoxious to speak about objectivity, progress and neutrality. From this relativism or scepticism, a more comprehensive and sincere perspective may ensue. Grammaticality is not the same with acceptability, the latter being related to the speaker's performance. The canon should be conceived in relation to the latter concept.

In Chomsky's vision, an acceptable sentence must appear natural and appropriate in a given text, besides it being grammatically irreproachable (Aspects of the Theory of Syntax. Cambridge, 1965). Acceptability has to take into account ambiguity and vagueness, concepts which have concerned semanticists and pragmatists for a while now.

We can infer that there are two ways to follow in relation to shaping the canon: on the one hand, we face the problem of communication; on the other 
hand, there is the problem of assessing and valuing. For instance, performative linguists will be interested in how people perform the verbal actions enacted by others (Douglas 4). Literary critics will tackle the axiological problem. In between, there are translators who have to fluidize and localize, but also to realize the selection in some specific situations.

Discourse theory may run the risk of reifying language by insisting on some ideologised stance. Preventively, inter-discourse communication constitutes an integrative and moderating paradigm. If we were to surpass the binary impasses of literature versus language, structural versus communicative approaches, language elitism versus language populism, and language versus culture, we should accept that languages are an issue of social justice (Philipps \& Gonzales XV). This means that the processes of communication and selection involve additional aspects besides competence and performance. The paradigm shifts stress the "hyphenated areas" of research, which implies both interdisciplinary and disciplinary delimitations (May 5). Otherwise put, relations between language and context, science and aesthetics should always be grammaticalized, whereas the canon formation needs to take into account the acceptability too.

\section{THE CANON VERSUS THE SUPER-ARCH-CANON}

The canon in the English speaking world has been remoulded under the influence of later developments in technology. Cultural studies, posthumanism, transhumanism, communication and performance studies, critical media studies, and translation studies joined efforts for the demythization of the aesthetic isolationism of the New Criticism. The new developments do not dispute the primacy of aesthetic/truthful criteria used for informing the canon, but they disclose the fact that we cannot ignore the complexity of contemporary society. My research envisages new approaches in selecting items for the new archcanon, with reference to specialized canons and also personal canons. How much is utopia and how much is dystopia in building an arch-canon in the English speaking world? Can we create a canon which will serve pure communicative purposes and not colonialist ones?

One of the applications of the canon is the creation of anthologies, which are distinct from miscellanies insofar as miscellanies collect writing on the same topic without a selective ordering. Anthologies, in their turn, inform the canon too, so their relationship is a two-way one. The term "anthology" comes from Greek where it originally indicated a "collection of flowers." It suggests evolution, hierarchy and institutionalization (Mujica 203-15), In Spain, for instance, the Biblioteca de Autores Espaňoles started in 1946 and was crucial in the designation of the canon. 
The canonical wars are waged at least at two levels: the theoretical one and the national one. For example, the American canon strove, at a certain stage, to strengthen the image of democratic nationalism and praised the works of Henry David Thoreau and Mark Twain. In parallel, the New Criticism encouraged those authors who stressed the formal aspects of texts.

In The Unusable Past (1986), Russell Reising describes three paradigm revolutions concerning the American canon: the genteel tradition of the transit from the $19^{\text {th }}$ to the $20^{\text {th }}$ century, the social and political approach to canon supported by critics such as Granville Hicks and V. L. Parrington, and Agrarian/New Critics approach. After World War II the movement for human and civil rights affected the cultural paradigm again. The monolithic tradition was fissured by the opening up of the canon, provoked by the acknowledgement of the minor traditions as integral and valuable components of the American cultural heritage.

A more flexible canon is the consequence of twists in literary and cultural theorizations. Marjorie Perloff, for instance, described the modern/postmodern divide as becoming more and more salient (in $21^{\text {st }}$ Century Modernism: The "New" Poetics). Contemporary researchers like Jennifer Ashton, a decade ago (Ashton 13), maintained the gap between modernism and postmodernism. In this sense, the irrelevance of the reader for the existence of the masterpiece is strongly preached in modernism (by Gertrude Stein, for example) and the reader's response is not something critical to literature. But the reader-response theory questions exactly such autonomous aestheticisms: could an author generate a masterpiece without nurturing the thought of an ideal (and imponderable) reader/receptor at least?

\section{CONCLUSION}

This line of research backs up Harold Bloom's plea for the aesthetic fibre of the canon which should resist the assault of the School of Resentment (feminists, post-colonialists, queer studies, subaltern studies). Consequently, it is not meant as a contestation, but surely it is meant as an impulse to enlarge the scope of the canon. In order to extract disciplinary research from its many cubicles and collocate the best results found, the new canon should admit to truth-value in addition to aesthetic qualities. In other words, the old artistic canon should become a component of the arch-canon. The new ethos of our culture includes the contributions of technology and communication. If we want to preserve the status of the canon, we have to acquiesce to a transdisciplinary canon, capacious enough and open to enlist all valuable research. 


\section{Works Cited}

Adams, Hazard. “Canons: Literary Criteria/Power Criteria”. Critical Inquiry, 14. 4 (Summer, 1988). 748-764. Chicago: University of Chicago Press. Print.

Allan, Keith \& Kasia M. Jaszezolt, eds. The Cambridge Handbook of Pragmatics. Cambridge: Cambridge University Press, 2012. Print.

Ashton, Jennifer. From Modernism to Postmodernism. American Poetry and Theory in the Twentieth Century. Cambridge: Cambridge University Press, 2005. Print.

Barker, Chris and Dariusz Galasinski. Cultural Studies and Discourse Analysis. A Dialogue on Language and Identity. California: SAGE Publications, 2001. Print.

Bauman, Zygmunt. Intimations of Postmodernity. London: Routledge, 1992. Print.

Bauman, Zygmunt. Liquid Modernity. New Jersey: Polity Press and Blackwell Publishing, LTD, 2000. Print.

Baxter, Leslie A. and Barbara M. Montgomery, Relating: Dialogues and Dialectics. New York: Guilford, 1996. Print.

Bertens, Hans. The Idea of the Postmodern: A History. London and New York: Routledge, 1995. Print.

Bloom, Harold. The Western Canon: The Books and School of Ages. New York: Harcourt Brace, 1994. Print.

Butler, Judith. “Longing for Recognition”. Studies in Gender and Sexuality. Roundtable on the Work of Jessica Benjamin. 1 (3): 271-290. 2000. Print.

Butler, Judith. "Performative and Gender Constitution: An Essay in Phenomenology and Feminist Theory”. Theater Journal. 40. 4 (Dec. 1988). 519-531. Baltimore: The Johns Hopkins University Press. Print.

Chomsky, Noam. Aspects of the Theory of Syntax. Cambridge MA: MIT Press, 1965. Print.

Connor, Ulla and Thomas A. Upton. Applied Corpus Linguistics. A Multidimensional Perspective. The Netherlands: Rodopi, 2004. Print.

Copstake, Ian D. (ed.). American Postmodernity: Essays on the Recent Fiction of Thomas Pynchon. Bern: Peter Lang, 2003. Print.

Corbett, John. An Intercultural Approach to English Language Teaching. Multilingual Matters Ltd, UK: Frankfurt Lodge, 2003. Print.

Douglas, Robinson. Performative Linguistics. London and New York: Routledge, 2004. Print.

Eco, Umberto. Kant and the Platypus. Essays on Language and Cognition. San Diego: A Harvest Book, Harcourt Inc., 1999. Print.

Eshelman, Raoul. "Performatism, or the End of Postmodernism”. Anthropoetics 6. No. 2, Fall 2000/Winter 2001. Web 23 September 2017. http://anthropoetics.ucla.edu/ap0602/perform/

Gair, Christopher. The American Counterculture. Edinburgh; Edinburgh University Press, 2007. Print.

Gair, Christopher. The Beat Generation: A Beginner's Guide. London: Oneworld Publications, 2008. Print.

Hyland, Ken and Brian Paltridge, eds. Continuum Companion to Discourse Analysis. London: Continuum International Publishing Group 2011. Print. 
Koskimaa, Raine. “Digital Literature. From Text to Hypertext and beyond”. Web. 1 October 2017. http://users.jyu.fi/ koskimaa/thesis/thesis.shtml.

Luzio, Aldo Di, Susanne Günthner and Franca Orletti. Culture in Communication Analyses of Intercultural Situations. Amsterdam/Philadelphia: John Benjamins Publishing Company, 2001. Print.

Mujica, Barbara. "Teaching Literature: Canon, Controversy and the Literary Anthology”. Hispania. 80, 2. May 1997. Print.

Pelevin, Viktor. The Blue Lantern and Other Stories. Cambridge: New Directions Publishing Corporation, 2000. Print.

Pelias, Ronald J. and James VanOosting. “A paradigm for Performance Studies”. The Quarterly Journal of Speech. No. 73, 219-231. 1987. Print.

Philipps, Alisson and Mike Gonzales. Modern Languages Learning \& Teaching in an Intercultural Field. London: Sage Publications, 2004. Print.

Rapport, Nigel and Joanna Overing. Social and Cultural Anthropology. The Key Concepts. London: Routledge, Taylor \& Francis e-Library, 2003. Print.

Scollon, Ron, Suzanne Wong Scollon. $2^{\text {nd }}$ ed. Intercultural Communication. A Discourse Approach. New Jersey: Blackwell Publishers, 2001. Print.

Searle, John R. An Essay in the Philosophy of Language. Cambridge: Cambridge University Press, 1969. Print.

Sela-Sheffy, Rakefet. "Canon formation revisited: canon and cultural production". Neohelicon. No. 2. XXIX (2002). 141-159. Print.

Sharman, Adam. Tradition and Modernity in Spanish American Literature: from Dario to Carpentier. New York: Palgrave MacMillan, 2006. Print.

Wilczek, Piotr. “The Literary Canon and Translation. Polish Culture as a Case Study”. Sarmatian Review. September 2012. Print.

Wise, Gene. “Paradigm Dramas”. American Quarterly. 31. 3. 293-337 (1979). Print.. 